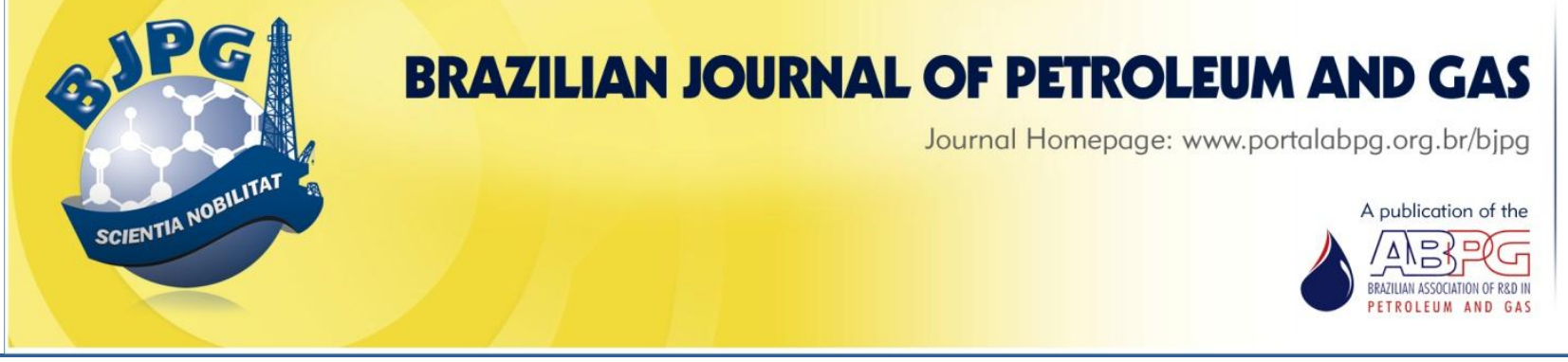

\title{
POTENTIAL OF GLYCEROL AND SOYBEAN OIL FOR BIOREMEDIATION OF WEATHERED OILY-SLUDGE CONTAMINATED SOIL
}

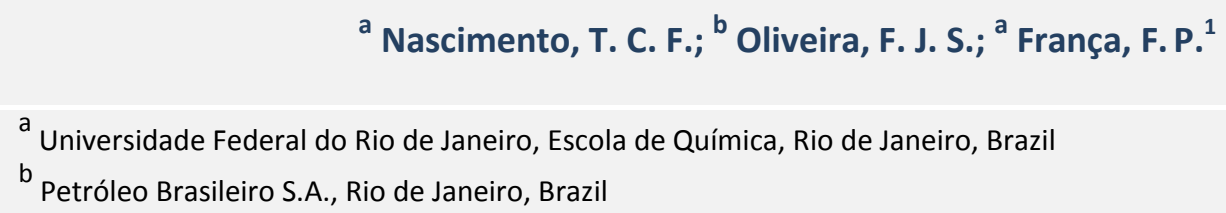

${ }^{\text {a }}$ Nascimento, T. C. F.; ${ }^{\text {}}$ Oliveira, F. J. S.; ${ }^{\text {}}$ França, F. P. ${ }^{1}$

a Universidade Federal do Rio de Janeiro, Escola de Química, Rio de Janeiro, Brazil

${ }^{\mathrm{b}}$ Petróleo Brasileiro S.A., Rio de Janeiro, Brazil

\begin{abstract}
The bioremediation of petroleum-contaminated soil was investigated on laboratory scale. This work evaluated the effect of co-substrate addition in tropical climate soil highly contaminated with oily residue. Glycerol and soybean oil were used as auxiliary co-substrates for contaminant degradation. Three different concentrations of co-substrate were tested, and the experiments were carried out over 60 days. The following parameters were monitored: humidity, $\mathrm{pH}$, total heterotrophic bacteria, total fungi, total petroleum hydrocarbons (TPH), and the concentrations of benzo[a]pyrene and chrysene. The soil supplementation with renewable co-substrates improved the efficiency of the biodegradation TPH, with removals of $85 \%$ and $83 \%$ for glycerol and soybean oil, respectively, compared to a $55 \%$ removal yielded by the biodegradation process without supplementation. The use of glycerol increased Chrysene and Benzo[a]pyrene biodegradation by $50 \%$, while soybean oil supplementation increased their removal by $36 \%$.
\end{abstract}

\section{KEYWORDS}

bioremediation; biodegradation; oily waste; glycerol; soybean oil

\footnotetext{
${ }^{1}$ To whom all correspondence should be addressed.

Address: Escola de Química, Universidade Federal do Rio de Janeiro, Av. Athos da Silveira Ramos, 149, Bloco E, SI E-201 - Ilha do Fundão Rio de Janeiro- Brazil - CEP 21941-909

Telephone / Fax: +55 21 2562-7621 / +55 21 2562-7567 | E-mail: fpfranca@eq.ufri.br doi:10.5419/bjpg2012-0004
} 


\section{INTRODUCTION}

One of the greatest unsolved issues in the oil and natural gas industry is the adequate disposal of oil residues, such as tank slops and sludge, generated in refinery thermal units. The costs related to sustainable and efficient treatment and disposal procedures for these residues are of great concern to both industrial and academic sectors. Society is concerned about these issues because all people are ultimately affected by hazardous events like oil spills that can happen on or offshore.

The biodegradation of oily waste into a contaminated soil is a recently developed treatment route. The objective of this treatment is to use the potential of natural soil microbiota to degrade the organic compounds in oily waste, decreasing its toxicity whenever adequate physical and chemical conditions for biodegradation are present (Huang et al., 2004). Biotechnological treatments not only are energy highly efficient but also cost less than conventional treatments. These treatments offer a large range of applications in terms of types and concentrations of contaminants (Oliveira and de França, 2005). While bioremediation is known for its low cost and its efficiency, it can be influenced by several factors, such as microbiota, climate, the weathering of contaminants, and the concentrations of organic compounds (Das et al., 2008; Marin et al., 2005). Soil structure is another important factor that influences bioremediation, as the solid matrix affects the availability of contaminants for the microbiota. For instance, the bioremediation of weathered soil with high concentrations of clay and silt can be difficult due to the decreased availabilities of the pollutants (Chaîneau et al., 2003; Gong et al., 2008). Polycyclic aromatic hydrocarbons (PAH) are toxic compounds that have become an environmental issue due to their high concentration in oily residues, being carcinogenic, and accumulating biologically (Haritash and Kauship, 2009). Additionally, the chemical structure of the 16 priority PAH listed by the United States Environmental Protection Agency (U.S. EPA) pollutant list may favor the sorption in soil particles, decreasing removal of the pollutants (Trindade et al., 2005).

A method to enhance biodegradation of hydrocarbons in natural soils may be the utilization of co-substrates, which can either play the role of alternate carbon source or act as mass transfer agent between the liquid phase of the soil and the solid matrix (Huang et al., 2004; Mellendorf et al., 2010). Commercial glycerol (GLY) and soybean oil (SBO) are renewable and low cost co-substrates, used to enhance process efficiency without increasing significantly bioremediation costs. This work investigates the potentials of GLY and SBO as auxiliary co-substrates in the bioremediation of a tropical soil with highly concentrated with weathered oily waste contamination.

\section{MATERIAL AND METHODS}

Soil originated from a landfarming area was collected from the Brazilian oil and gas industry located in the north of the country. All the samples were taken at a depth of $15 \mathrm{~cm}$ from the surface.

\subsection{Physical analysis}

Soil size distribution analysis was performed using conventional screen procedures for the separation of stones and sand. Screening was followed by sedimentation of fine materials in sodium ortho-phosphate solution. Soil water content was determined using porcelain crucibles and an infrared humidity analyzer. Soil $\mathrm{pH}$ values were measured in 1:1 (w/w) distilled water suspensions. The water holding capacity (WHC) of the soil samples were determined by weight analysis (Watwood et al., 1991).

\subsection{Chemical analysis}

To determine Total Petroleum Hydrocarbon (TPH), the soil samples were supplemented with deuterated tricontane. Samples were submitted to 16 EPA priority determinations, and deuterated $\mathrm{PAH}$ compounds were used as standards. The samples were subjected to Soxhlet extractions with ultra pure methylene chloride for $16 \mathrm{~h}$ according to EPA Method 3540C (EPA, 1996). The extracted phase was submitted to a cleanup procedure in a silica gel chromatographic column according to EPA Method 3630 (EPA, 1996). The sample volume was reduced to $1 \mathrm{~mL}$ under $\mathrm{N}_{2}$. TPH was measured following EPA Method 8015 (EPA, 1996) using a Thermo Finnigan Focus gas chromatograph equipped with a DB-5 capillary column and a flame ionization detector. PAH, on the other hand, were quantified using EPA Method 8270 (EPA, 1996) 
with a Thermo Finnigan Focus gas chromatograph equipped with DB-5-MS column and a DSQ 2 Thermo Finnigan mass spectrometer operating at selective ion mode (less than 3 cycles/s).

Total nitrogen and total phosphorus were measured by conventional methods using a UV-Vis spectrophotometer according to methods described previously (Embrapa, 1997).

\subsection{Microbiological count}

Quantification of the microbiological groups present in the soil samples, both Total Heterotrophic Bacteria (THB) and Total Fungi (TF), was conducted using the pour plate Technique. A $0.9 \%(\mathrm{~m} / \mathrm{v}) \mathrm{NaCl}$ solution $(90 \mathrm{~mL})$ was transferred to Erlenmeyer flasks containing $10 \mathrm{~g}$ of soil samples, which were shaken for $15 \mathrm{~min}$ at 150 RPM. Samples $(1 \mathrm{~mL})$ were submitted to a successive dilution procedure and cultivated in a culture medium specific to each microbial group. Agar Sabouraud with glucose $2 \%(\mathrm{~m} / \mathrm{v})$ was used for TF while the Agar Nutrient Medium was used for THB. The plates were placed in a bacterial incubator at $30 \pm 1^{\circ} \mathrm{C}$ for $48 \mathrm{~h}$ for bacterial cell growth and counting and for $120 \mathrm{~h}$ for fungi cell growth and counting. The results were expressed as colonyforming units per gram of dry soil (CFU/g dry soil). All microbiological counts and experiments were carried out in triplicate.

\subsection{Bioremediation tests}

Biodegradation experiments were conducted in polyethylene reactors $20 \mathrm{~cm}$ long, $20 \mathrm{~cm}$ wide and $10 \mathrm{~cm}$ high. Contaminated soil $(2 \mathrm{~kg})$ was added to each reactor, and the soil humidity was adjusted to
$20-25 \%$, which corresponds to $70-80 \%$ of the soil water holding capacity (Watwood et al., 1991).

THB, TF, TPH, PAH, $\mathrm{pH}$, and moisture were monitored throughout the process. The potential of two co-substrates - GLY and SBO - in the biodegradation of TPH was tested. Commercial soybean oil was used. Each co-substrate soil was supplemented with 375,750 , and $1500 \mathrm{mg}$ of cosubstrate per $\mathrm{kg}$ of soil. To guarantee oxygen supply, the soil was aerated manually every $72 \mathrm{~h}$ using a glass stirring rod. Soil sampling for experimental analysis was carried out by collecting $10 \mathrm{~g}$ of the soil from three equidistant locations. This was performed to mix and to homogenize the soil samples to get a unique final sample. To determine abiotic losses, control tests were carried out using a silver nitrate solution $10 \%(\mathrm{~m} / \mathrm{v})$ biocide instead of water in moisture control. All tests were conducted in triplicate, and the results were presented as the mean of the three independent experiments. Blank tests were executed without co-substrate supplementation using same procedure for water addition and aeration.

\section{RESULTS AND DISCUSSION}

Some parameters related to the physical and chemical characterization of the soil are presented in Table 1. The contaminated soil contained 38\% fine materials (clay and silt). Although clay and silt have high surface areas, the sorption phenomenon of contaminants on these materials was favored, making it harder for contaminants less bioavaliable. Hydrocarbon degradation by bacteria and fungi were favored at $\mathrm{pH}$ values close to

Table 1. Physical and chemical characterization of soil.

\begin{tabular}{lc}
\hline \multicolumn{1}{c}{ Parameters } & Results \\
\hline $\mathrm{pH}$ (in distilled water) & $6.9 \pm 0.2$ \\
Clay (\%) & $13 \pm 1$ \\
Silt (\%) & $25 \pm 2$ \\
Fine Sand (\%) & $18 \pm 1$ \\
Medium Sand (\%) & $28 \pm 2$ \\
Coarse Sand (\%) & $12 \pm 1$ \\
Water Holding Capacity (WHC) (\%) & $32 \pm 1$ \\
Total P (mg P/kg) & $16 \pm 1$ \\
Total N (mg N/kg) & $680 \pm 50$ \\
TPH (mg/kg) & $29,179 \pm 450$ \\
\hline
\end{tabular}




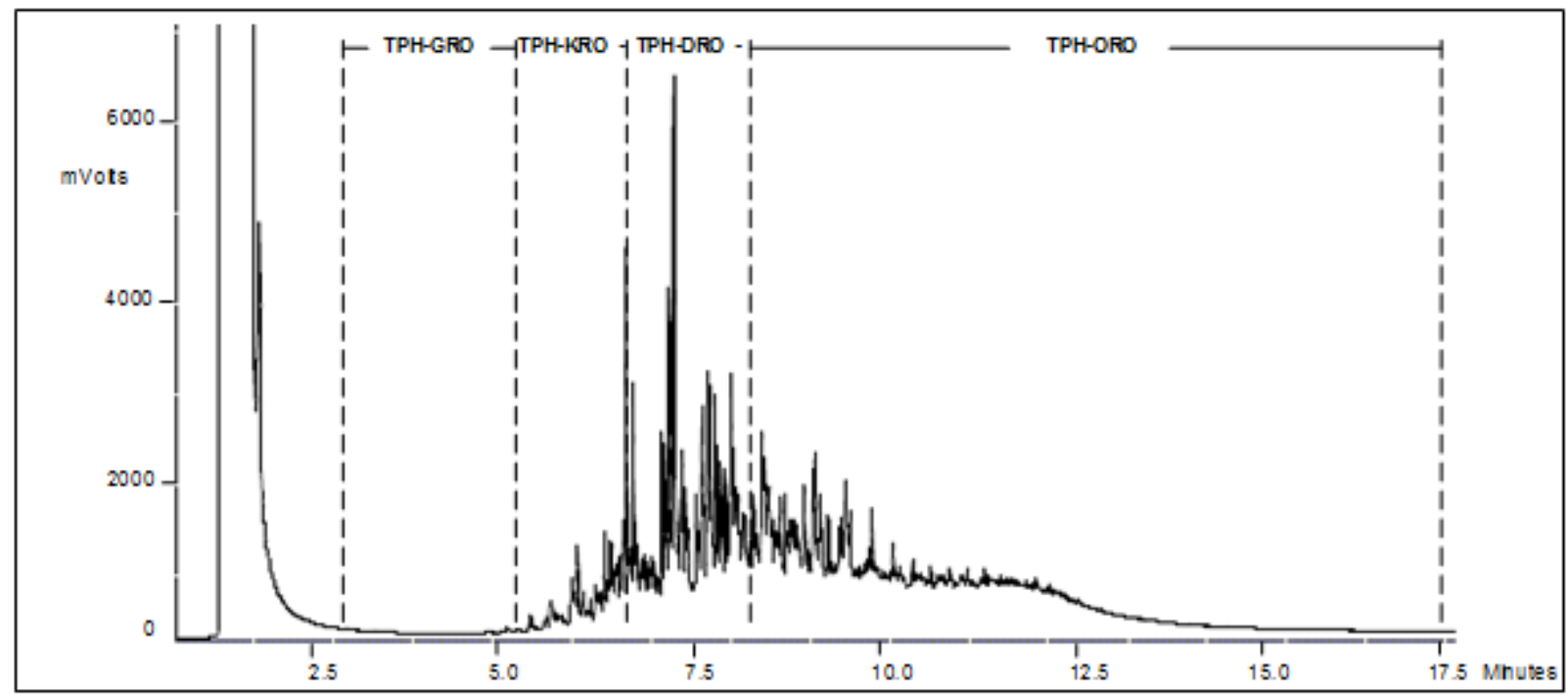

Figure 1. TPH chromatogram of contaminated soil before bioremediation.

neutral (Franco et al., 2004). A WHC of approximately $30 \%$ was consistent with weathered soils. A slightly acidic $\mathrm{pH}$ is characteristic of clay minerals, which was in agreement with the granulometric distribution observed.

The chromatogram of the soil organic extract (Figure 1) presented an Unsolved Complex Mixture (UCM) or organics, and neither pristane nor phytane were detected. The following organic compounds were present in the UCM: gasoline (TPH GRO), 4\%; kerosene (TPH-KRO), 1\%; diesel (TPH DRO), 5\%; and lubricants (TPH ORO), 90\% $(\mathrm{w} / \mathrm{w})$. The absence of pristane and phytane, the concentrations of TPH GRO and TPH DRO, and the elevated base line suggested that the weathering process was taking place in the petroleum waste, increasing the difficulty of biotreatment. In fact, the hazardousness of the residue is a result of chemical, physical, and biological processes occurring within the residue that may affect the types of compounds that remain in the soil. In addition, a high concentration of TPH was observed, which also makes bioremediation difficult (Del'Arco and de França, 2001). Among the 16 U.S. EPA priority PAHs, the soil contained chrysene (CHR) and benzo[a]pyrene (BaP) as predominant compounds, with concentrations of 21,640 and $41,048 \mu \mathrm{g} / \mathrm{kg}$, respectively. Other PAHs were detected at concentrations very close to the sample quantification limit $1,083 \mu \mathrm{g} / \mathrm{kg}$ for each $\mathrm{PAH}$.
All of the bioremediation assays began with a $\mathrm{pH} 6.9 \pm 0.1$, decreasing slightly through the test period (60 days), reaching values of 6.5 for the tests without co-substrates and 6.0 for the tests with co-substrates. The decrease in $\mathrm{pH}$ may be explained by the fact that when the microbiota present in the soil are active, the metabolic breakdown of the light and heavy fractions of petroleum produces several types of organic acids which, in turn, reduce $\mathrm{pH}$ (Watson et al., 2002). It is also important to report that soil phyllosilicates, iron, and aluminium oxyhridroxides may provide some buffering capacity, contributing to the slight $\mathrm{pH}$ decrease.

During the tests, the soil moisture was kept between 70 to $80 \%$ of the WHC, which is considered ideal for biodegradation processes (Ramírez et al., 2009). Another reason to maintain the soil moisture in that range is that a greater percentage of water would decrease oxygen dispersion in the soil, demanding greater effort to accomplish the aerobic biodegradation of hydrocarbons (Marin et al., 2005). The aqueous phase in soil enhances the microbial solid/liquid interface, facilitates contaminant transport to the microbial cells, and permits the diffusion of microbial excreta. In addition, water competes for the same binding sites as PAH in the solid phase of soil, resulting in an increase in the degree of desorption of these organics. 


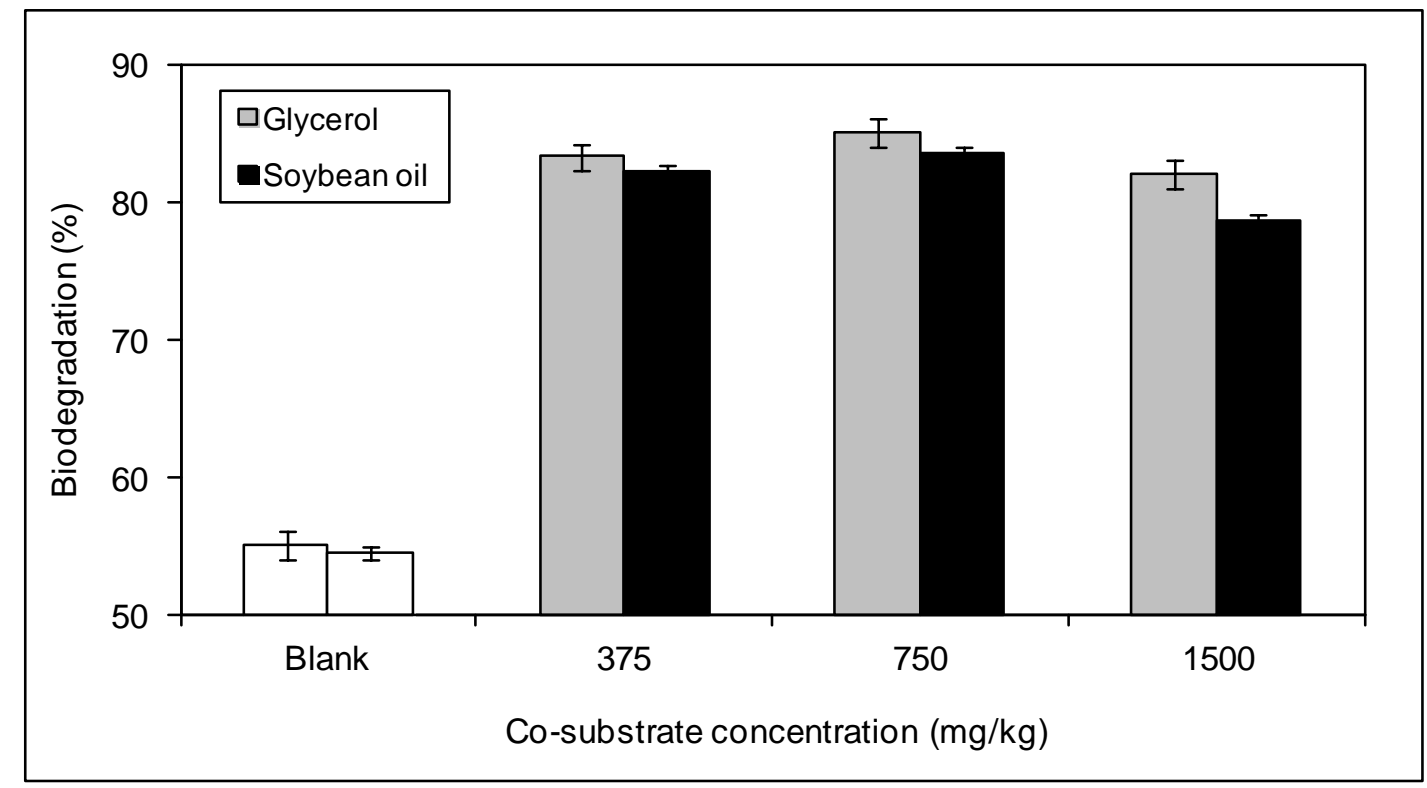

Figure 2. Bioremediation tests with glycerol and vegetable oil supplementation at 60 days.

To reduce process costs, soil temperatures were not controlled. During the 60-day experiment, soil temperatures remained at $30 \pm 2^{\circ} \mathrm{C}$. Temperatures between 25 and $30^{\circ} \mathrm{C}$ are suitable for the growth of a great variety of species of microorganisms capable of oxidizing hydrocarbons (Olivier and Magot, 2005). Also, laboratory experiments indicate that hydrocarbons degradation by microorganisms is best conducted at temperatures between 20 and $35^{\circ} \mathrm{C}$.

Abiotic losses were less than $10 \%$. Abiotic losses are attributed to volatilization and photo-oxidation (Imfeld et al., 2009). Regardless of the co-substrate used, there was a decrease in soil TPH concentration during the 60 -day process (Figure 2). Both GLY and SBO supplements, at concentrations of 375 and $750 \mathrm{mg}$ of co-substrate per kg of soil, produced good results, provided that TPH were lower than $5 \mathrm{~g} / \mathrm{kg}$ of soil, which is the limit for intervention for fine soils in industrial areas according to an international quality standard (Netherlands Government Gazette, 1994). When the soil was supplemented with $1500 \mathrm{mg}$ of cosubstrate per $\mathrm{kg}$ of soil, biodegradation was slightly reduced, most likely because soil microorganisms biodegraded the co-substrate to the exclusion of the contaminants (Silva et al., 2010). U.S. EPA Method 8015 reports the concentrations of extractable hydrocarbons, sometimes referred to as gasoline, kerosene, diesel, and oil range organics; or TPH GRO, TPH KRO, TPH DRO and TPH ORO, respectively, because the boiling point ranges of the hydrocarbons in each roughly correspond to

Table 2. Biodegradation of Chrysene and Benzo[a]pyrene.

\begin{tabular}{|c|c|c|c|}
\hline & Co-substrate & Biod & (\%) \\
\hline Type & $\begin{array}{l}\text { Concentration (mg of co- } \\
\text { substrate/kg of soil) }\end{array}$ & $\mathrm{CHR}$ & $\mathrm{BaP}$ \\
\hline \multirow{3}{*}{ خे } & 375 & $38 \pm 2$ & $30 \pm 1$ \\
\hline & 750 & $55 \pm 2$ & $53 \pm 2$ \\
\hline & 1500 & $19 \pm 1$ & $35 \pm 2$ \\
\hline \multirow{3}{*}{$\begin{array}{l}\stackrel{0}{\sim} \\
\text { ヘ }\end{array}$} & 375 & $38 \pm 2$ & $31 \pm 2$ \\
\hline & 750 & $41 \pm 2$ & $36 \pm 3$ \\
\hline & 1500 & $22 \pm 2$ & $17 \pm 2$ \\
\hline
\end{tabular}




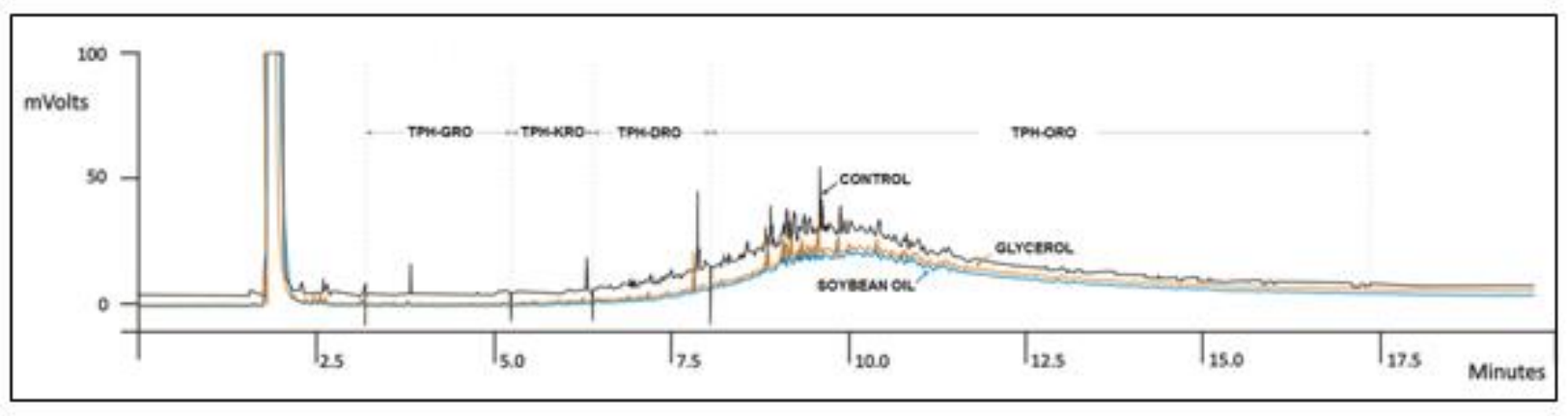

Figure 3. TPH chromatogram during bioremediation tests with glycerol and vegetable oil supplementation at 60 days.

those of gasoline ( $C_{6}$ to $\left.C_{10-12}\right)$, kerosene $\left(C_{11}\right.$ to $\left.C_{14}\right)$, diesel fuel $\left(C_{8-12}\right.$ to $\left.C_{24-26}\right)$, and oil $\left(C_{20}\right.$ to $\left.C_{28-C 30}\right)$, respectively. The chromatographic profiles (Figure 3) from the soil organic extracts from soils that had been supplemented with co-substrates confirm that TPH GRO and TPH KRO were strongly biodegraded. TPH ORO was degraded to a great extent despite its recalcitrant nature, clearly indicating native microbiota adaptation.

In contrast to results reported by Del'Arco and de França (2001), who worked with sandy soil contaminated with Light Arab oil, with TPH concentrations not greater than $14 \mathrm{~g} / \mathrm{kg}$ of soil, due to inhibitory effects, the initial hydrocarbon concentration of approximately $29 \mathrm{~g} / \mathrm{kg}$ of tropical soil did not exhibit bioprocess inhibition, illustrating the need to investigate each system and the potential of its soil microbiota individually. This work used landfarming soil for the treatment of oily wastes; therefore, the native microbiota was already adapted, contributing to the removal of hydrocarbons.

Regarding $\mathrm{CHR}$ and BaP biodegradation, both SBO and GLY enhanced PAH biodegradation (Table 2). PAHs are very toxic compounds, being of great interest in contaminated sites. CHR has four aromatic rings while $\mathrm{BaP}$ has five condensed rings. These compounds are classified as PAHs of high molecular weight (Daugulis and McCracken, 2003), having low vapor pressures and tending to remain adsorbed on the soil fine material, inhibiting biodegradation. High molecular weight PAHs are less biodegradable than those having low molecular weights (Alexander, 1999; Atagana et al., 2006; Vasconcelos et al., 2011), which is related to the bioavailability of the compounds.
The use of co-substrates increased $\mathrm{CHR}$ and BAP removal, with a co-substrate concentration of 750 $\mathrm{mg} / \mathrm{kg}$ resulting in the greatest removal of the two PAHs for both types of co-substrates. Another issue to be taken into account is the soil intemperism (with a soil fine particle content of $38 \%$ clay and silt), which increases the sorption of hydrophobic organic contaminants such as PAH in the solid matrix, decreasing the rate and extension of biodegradation. In intemperised soils, the transfer of pollutants is the step that limits the bioprocess (Nocentini et al., 2000). Glycerol is a water soluble carbon source that is more available as a nutrient to different types of microorganisms. Because GLY is able to enhance biosurfactant production, it can have a favored bioremediation process (Calvo et al., 2009; Silva et al., 2010). Soybean oil may have helped in the mass transfer of contaminants from the solid matrix to the microbiota present in the soil (Yapa et al., 2010). Hence, the effects of both co-substrates on soil biotreatment are clear.

The behavior of microorganisms is related profoundly to the biodegradation parameters, and the test results reveal a great deal about the process. The tests supplemented with $750 \mathrm{mg}$ of cosubstrate per $\mathrm{kg}$ of soil are presented in Figures $4 \mathrm{a}$ and $4 \mathrm{~b}$. The initial concentrations of THB and TF were the same in all the tests, and the curve profiles were similar. THB and TF concentrations reached their maximum values after 7 days and then started to decrease, with THB concentrations reaching their minimum values after 60 days and TF concentrations reaching minimum values after 45 days for both co-substrates. These values are compatible with values reported in the literature for soils contaminated with petroleum and other refinery products (Oliveira and de França, 2005). 


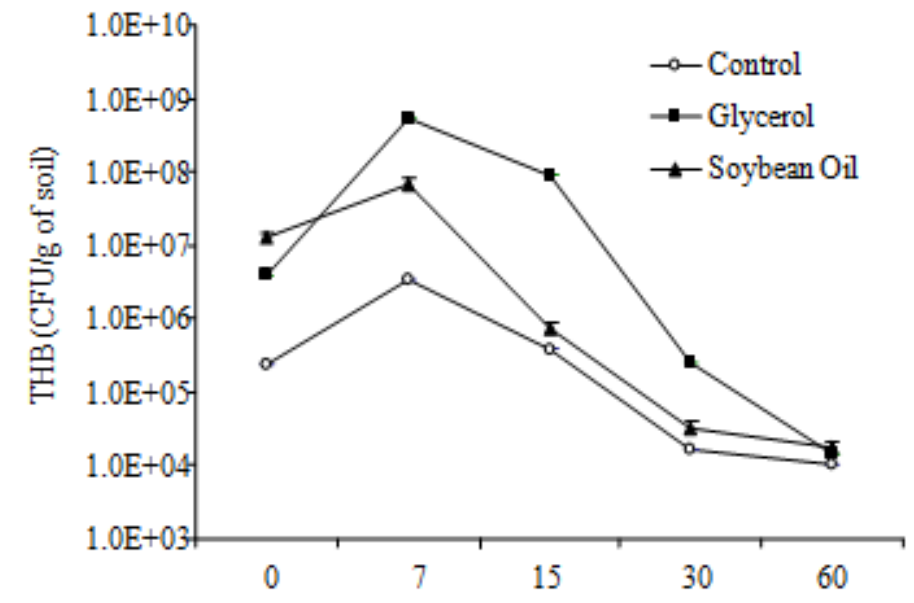

(a)

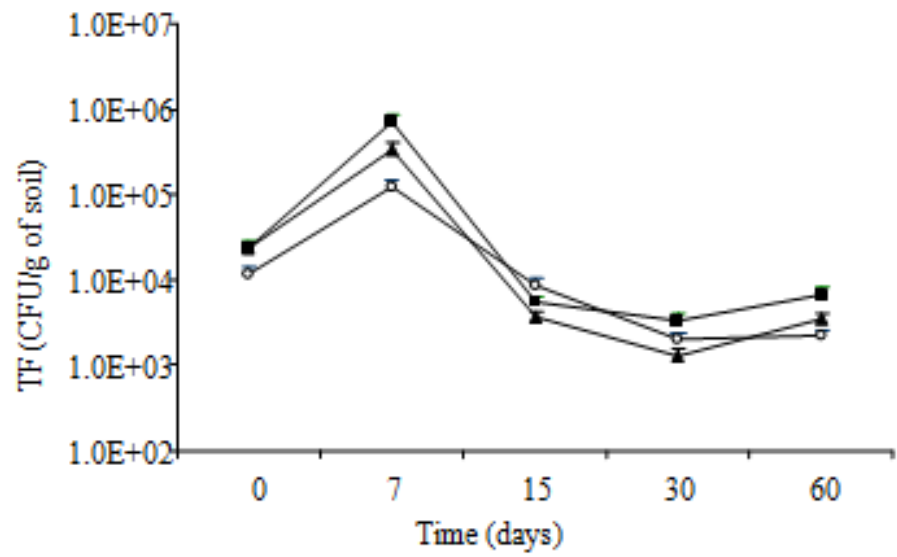

(b)

Figure 4. Microbial growth during bioremediation - (a) Total Heterotrophic Bacteria (THB) and (b) Total Fungi (TF).

Figures $4 \mathrm{a}$ and $4 \mathrm{~b}$ reveal that: 1) microbial concentrations increased during 7 days of the process, so the contaminated soil initially had noninhibitory concentrations of macronutrients ( $\mathrm{N}$ and P), which are important elements for biomass production; 2) co-substrate supplementation favored bacteria growth but only influenced fungal metabolism slightly, which exhibited similar profiles with or without supplementation with either co-substrate. This result is corroborated with findings reported in the literature (Atagana et al., 2006; Pérez-Armendáriz et al., 2010, Tortella et al., 2005), in which filamentous fungi were identified as microorganisms with great capabilities of degrading hydrocarbons, especially the heavy fractions of petroleum such as those found in oily sludge.

\section{CONCLUSIONS}

GLY and SBO were used as co-substrates in the biodegradation of oily waste in contaminated soil. At a concentration of $750 \mathrm{mg}$ of co-substrate per $\mathrm{kg}$ of soil, each co-substrate attained optimal TPH and $\mathrm{PAH}$ removals in terms of $\mathrm{CHR}$ and $\mathrm{BaP}$ removal from an intemperized soil. Sorption of organic hydrophobic contaminants to the solid matrix is favored in this type of soil, decreasing the rate and extension of biodegradation. The supplementation of co-substrates is of great importance because it can favor contaminant mass transfer from the solid matrix to microorganisms. The use of the cosubstrates also increased THB and TF, enhancing soil biotreatment. As GLY is an abundant byproduct of biodiesel production, its utilization as a 
co-substrate in contaminated soil bioremediation constitutes an important product destination. Finally, the potentials of GLY and SBO for biotreatment of soil were verified experimentally.

\section{ACKNOWLEDGEMENTS}

The authors wish to thank CNPq and CAPES for their financial support.

\section{REFERENCES}

Alexander, M. Biodegradation and Bioremediation, San Diego: Academic Press, 1999.

Atagana, H. I; Haynes, R. J; Wallis, F. M. Fungal bioremediation of creosote contaminated soil: A laboratory scale bioremediation study using indigenous soil fungi. Water Air and Soil Pollution, v.172, p. 201-219, 2006.

http://dx.doi.org/10.1007/s11270-005-9074-x

Calvo, C.; Manzanera, M.; Silva-Castro, G. A.; Uad, I.; González-López, J. Review. Application of bioemulsifiers in soil oil bioremediation processes. future prospects. Science of the Total Environment, v. 407, p. 363-3640, 2009. http://dx.doi.org/10.1016/i.scitotenv.2008.07.008

Chaîneau, C. H.; Yéprémian, C.; Vidalie, J. F.; Ducreux, J.; Ballerini, D. Bioremediation of a crude oil polluted soil: biodegradation, leaching and toxicity assessments. Water Air and Soil Pollution, v. 144, p. $419-440,2003$.

http://dx.doi.org/10.1023/A:1022935600698

Das, P.; Mukherjee, S; Sen, R. Improved bioavailability and biodegradation of a model polyaromatic hydrocarbon by a biosurfactant producing bacterium of marine origin. Chemosphere, v. 72, p. 1229-1234, 2008. http://dx.doi.org/10.1016/i.chemosphere.2008.05.015

Daugulis, A. J.; McCracken, C. M. Microbial degradation of high and low molecular weight polyaromatic hydrocarbons in a two-phase partitioning bioreactor by two strains of Sphingomonas sp. Biotechnology Letters, v. 25, p. 1421-1424, 2003.

http://dx.doi.org/10.1023/A:1025099427538
Del'Arco J. P.de França, F. P. Influence of oil contamination levels on hydrocarbon biodegradation in sandy sediment. Environmental Pollution, v. 110, p. 515-519, 2001. http://dx.doi.org/10.1016/S0269-7491(00)00128-7

Embrapa - Empresa Brasileira de Pecuária e Agricultura. Manual de Métodos de Análise de Solos, Rio de Janeiro, 1997. (in portuguese).

EPA - United States Environmental Protection Agency, Test Methods for Evaluating Solid Waste, SW-846, USEPA Office of Solid Waste and Emergency Response, Washington DC, 1996.

Franco, I.; Contin, M.; Bragato, G.; de Nobili, M. Microbial resilience of soils contaminated with crude oil. Geoderma, v. 121, p. 17-30, 2004. http://dx.doi.org/10.1016/j.geoderma.2003.10.002

Gong, Z.; Li, P.; Wilke, B. M.; Alef, K. Effects of vegetable oil residue after soil extraction on physical-chemical properties of sandy soil and plant growth. Journal of Environmental Science, v. 20, p. 1458-1462, 2008. http://dx.doi.org/10.1016/S1001$\underline{0742(08) 62549-8}$

Haritash, A. K.; Kaushik, C. P. Biodegradation aspects of polycyclic aromatic hydrocarbons (PAHs): a review. Journal of Hazardous Materials, v. 169, p. 1-15, 2009.

http://dx.doi.org/10.1016/i.jhazmat.2009.03.137

Huang, X. D.; El-Alawi, Y.; Penrose, D. M.; Glick, B. R.; Grenberg, B. M. Responses of three grass species to cresote during phytoremediation. Environmental Pollution, v. 130, p. 453-464, 2004. http://dx.doi.org/10.1016/i.envpol.2003.12.018

Imfeld, G.; Braeckevelt, M.; Kuschk, P.; Richnow, H. H. Monitoring and assessing processes of organic chemicals removal in constructed wetlands. Chemosphere, v. 74, p. 349-362, 2009. http://dx.doi.org/10.1016/j.chemosphere.2008.09.062

Marin, J. A.; Hernandez, T.; Garcia, C. Bioremediation of oil refinery sludge by landfarming in semiarid conditions: influence on soil microbial activity. Environmental Research, v. 98, p. 185-195, 2005.

http://dx.doi.org/10.1016/i.envres.2004.06.005 
Mellendorf, M.; Soja, G.; Martin, H.; Gerzabek, M. H.; Watzinger, A. Soil microbial community dynamics and phenanthrene degradation as affected by rape oil application. Applied Soil Ecology, v. 46, p. 329-334, 2010.

http://dx.doi.org/10.1016/i.apsoil.2010.10.008

Netherlands Government Gazette (1994). Intervention values soil remediation. Netherlands Government Gazete 95, May, 24, 1994.

Nocentini, M.; Pinelli, D.; Fava, F. Bioremediation of a soil contaminated by hydrocarbon mixtures: the residual concentration problem. Chemosphere , v. 41, p. 1115-1123, 2000. http://dx.doi.org/10.1016/S0045-6535(00)00057-6

Oliveira, F. J. S.; de França, F. P. Increase in removal of polycyclic aromatic hydrocarbons during bioremediation of crude oil-contaminated sandy soil. Applied Biochemistry and Biotechnology, v. 121, p. 124:593-603, 2005.

Olivier, B.; Magot, M. Petroleum Microbiology. ASM Press, Washington D. C., 2005.

Pérez-Armendáriz, B.; Martínez-Carrera, D.; Calixto-Mosqueda, M.; Alba, J.; Rodríguez-Vázquez, R. Filamentous fungi remove weathered hydrocarbons from polluted soil of tropical Mexico. Revista Internacional de Contaminación Ambiental, v. 26 (3), p. 193-199, 2010.

Ramírez, M. E.; Zapién, B.; Zegarra.; H. G.; Rojas, N. G.; Fernández, L. C. Assessment of hydrocarbon biodegradability in clayed and weathered polluted soils. International Biodeterioration and Biodegradation, v. 63, p. 347-353, 2009. http://dx.doi.org/10.1016/j.ibiod.2008.11.010

Silva, S. N. R. L.; Farias, C. B. B.; Rufino, R. D.; Luna, J. M.; Sarubbo, L. A. Glycerol as substrate for the production of biosurfactant by Pseudomonas aeruginosa UCP0992. Colloids and Surfaces. B, Biointerfaces, v. 79, p. 174-183, 2010. http://dx.doi.org/10.1016/j.colsurfb.2010.03.050
Tortella, G. R.; Diez, M. C.; Durán, N. Fungal diversity and use in decomposition of environmental pollutants. Critical Reviews in Microbiology, v. 31, p. 197-212, 2005. http://dx.doi.org/10.1080/10408410500304066

Trindade, P. V. O.; Sobral, L. G.; Rizzo, A. C. L.; Leite, S. G. F.; Soriano, A. U. Bioremediation of a weathered and a recently oil-contaminated soil from Brazil: a comparison study. Chemosphere, v. 58, p. 515-522, 2005.

http://dx.doi.org/10.1016/i.chemosphere.2004.09.021

Vasconcelos, U.; Oliveira, F. J. S.; de França, F. P. Removal of high-molecular weight polycyclic aromatic hydrocarbons. Química Nova, v. 34, p. 218-221, 2011. http://dx.doi.org/10.1590/S0100$\underline{40422011000200009}$

Watson, J.S.; Jones, D. M.; Swannellb, R. P. J.; van Duina, A.C.P. Formation of carboxylic acids during aerobic biodegradation of crude oil and evidence of microbial oxidation of hopanes. Organic Geochemistry, v. 23, p. 1153-1169, 2002. http://dx.doi.org/10.1016/S0146-6380(02)00086-4

Watwood, M. E.; White, C. S.; Dahn, C. N. Methodological modifications for accurate and efficient determination of contaminant biodegradation in unsaturated calcareous soil. Applied and Environmental Microbiology, v. 57, p. 717-720, 1991.

Yapa, C. L.; Gana, S.; Ng, H. K. Application of vegetable oils in the treatment of polycyclic aromatic hydrocarbons-contaminated soils. Journal of Hazardous Materials, v. 177, p. 28-41, 2010. http://dx.doi.org/10.1016/j.jhazmat.2009.11.078 